\title{
Pemanfaatan Teknologi Terhadap Promosi dan Penjualan Hasil Pertanian (Studi Kasus: Membangun E-Agriculture pada Budidaya Jamur)
}

\author{
Seva Novika ${ }^{1}$, Enriko Putra Wibowo ${ }^{2}$ \\ sevanovika_syariah@radenfatah.ac.id ${ }^{1}$, putraenriko@gmail.com ${ }^{2}$ \\ ${ }^{1}$ Jurusan Sistem Informasi, Fakultas Sains dan Teknologi, UIN Raden Fatah Palembang \\ ${ }^{2}$ Jurusan Sistem Informasi, Fakultas Sains dan Teknologi, UIN Raden Fatah Palembang
}

Diterima: 21 Januari 2019|Direvisi: 10 April 2019|Disetujui: 10 Juni 2019

(C) 2019 Program Studi Sistem Informasi Fakultas Sains dan Teknologi,

Universitas Islam Negeri Raden Fatah Palembang, Indonesia

\begin{abstract}
Abstrak: Pemanfaatan Teknologi Informasi dalam proses pemasaran suatu produk sangat dibutuhkan karena mampu memperluas promosi dan penjualan, khususnya di bidang pertanian. Budidaya jamur rian sudah sejak lama berdiri, masyarakat atau petani setempat masih bergantung dengan membudidayakan jamur tapi saat ini dengan berkembangnya zaman petani banyak yang beralih profesi dikarenakan sulitnya mempromosikan dan menjual hasil jamur yang telah dihasilkan. Pemasaran jamur oleh pemilik harus mengikuti perkembangan teknologi sekarang ini, oleh karena itu perlu adanya pengembangan dalam promosi dan penjualan jamur berupa aplikasi E-Agriculture. Pengembangan E-Agriculture menggunakan metode air terjun (waterfall), dengan adanya aplikasi ini mampu membantu promosi dan penjualan khususnya hasil dari budidaya Jamur.
\end{abstract}

Kata Kunci: E-Agriculture, Teknologi, Pertanian

Abstract: The Role of Information Technology in the marketing process of a product is needed because it is able to expand promotion and sales, especially in agriculture. Rian's mushroom cultivation has long been established, local people or farmers still depend on cultivating mushrooms but nowadays with the development of many peasants who are shifting proposals due to the difficulty of promoting and selling the mushrooms that have been produced. Mushroom marketing by the owner must keep up with current technological developments, because of that there needs to be development in the promotion and sale of mushrooms in the form of E-Agriculture application. E-Agriculture development uses the Waterfall method, with this application being able to help promotion and sales especially the results of Mushroom cultivation.

Keywords: E-Agriculture, Technology, Agriculture

\section{PENDAHULUAN}

Pemanfaatan Teknologi Informasi dalam proses pemasaran suatu produk sangat dibutuhkan karena mampu memperluas promosi dan penjualan. Budidaya jamur rian sudah lama berdiri sejak tahun 1990an, petani setempat masih bergantung dengan membudidayakan jamur tapi saat ini dengan berkembangnya zaman masyarakat banyak yang beralih profesi dikarenakan sulit nya mempromosikan dan menjual hasil jamur yang telah di hasilkan. Saat ini Jamur Rian hanya mempromosikan hasil jamurnya hanya lewat media sosial. Selain media sosial dibutuhkan juga aplikasi untuk memperluas promosi dan penjualan serta pengelolaan administrasi seperti laporan penjualan jamur dan bibit jamur.

E-Agriculture atau E-Agribusiness sendiri diambil dari definisi (electronic) dalam konsep Information and Communication Technology (ICT), yaitu kegiatan pertanian dan/atau agribisnis yang memanfaatkan keunggulan ICT seperti komputer, internet, piranti lunak (software) dan piranti keras (hardware), radio, televisi dan perangkat IT lainnya, serta orang yang mengoperasikan ICT tersebut (Soekartawi, 2007). Aplikasi E-Agriculture atau E- 
Agribusiness dapat dilakukan di semua aktivitas pertanian mulai dari kegiatan di hulu (proses produksi) sampai pada di hilir (pemasaran hasil). Pemanfaatan teknologi dalam Pertanian Kini ICT juga dicoba untuk mendorong agar pertanian Indonesia mampu bersaing. Hal ini dapat dimengerti karena peran ICT sering menonjol, apakah itu di kegiatan teknologi produksi maupun di kegiatan teknologi informasi. Dengan demikian, lambat atau cepat, maka pelaku agribisnis di Indonesia harus bisa menguasai teknologi tersebut.

Pengembangan E-Agriculture pada Budidaya Jamur Rian dilakukan dengan menggunakan metode air terjun (waterfall), mulai dari analisis kebutuhan, desain sistem, implementasi, verifikasi, dan maintenance. Dengan memanfaatkan teknologi berupa pengembangan aplikasi ini dapat membantu memperluas promosi dan penjualan hasil pertanian, khususnya budidaya jamur.

\section{METODOLOGI PENELITIAN}

\subsection{Metode Pengumpulan Data}

Untuk memperoleh gambaran mengenai data yang dibutuhkan dalam pembuatan laporan ini metode yang digunakan yaitu:

a. Observasi

Observasi merupakan teknik mendapatkan data dengan cara mengamati langsung objek datanya (Jogiyanto, 2008). Teknik observasi dalam penelitian ini digunakan untuk mengamati langsung dan mencatat permasalahan yang sedang terjadi pada budidaya jamur Rian yang berlokasi di Jln. Sukarela Km7. Lorong Perjuangan.

b. Wawancara

Proses wawancara dilakukan melalui komunikasi dua arah dengan pihak terkait untuk memperoleh data (Jogiyanto, 2008). Teknik ini digunakan oleh penulis untuk mendapatkan informasi dengan pemilik Budidaya Jamur yaitu sdr Rian.

c. Studi Pustaka

Dilakukan dengan cara mengumpulkan data-data dari sumber seperti buku, skripsi, jurnal, sehingga dapat dijadikan sebagai bahan acuan dalam penulisan ini.

\subsection{Metode Pengembangan Sistem}

Metode yang digunakan untuk membangun E-Agriculture ini adalah metode waterfall. Metode air terjun atau yang sering disebut metode waterfall sering dinamakan siklus hidup klasik (classic life cycle), dimana hal ini menggambarkan pendekatan yang sistematis dan juga berurutan pada pengembangan perangkat lunak, dimulai dengan spesifikasi kebutuhan pengguna lalu berlanjut melalui tahapan-tahapan perencanaan (planning), pemodelan (modeling), konstruksi (construction), serta penyerahan sistem ke para pelanggan/pengguna (deployment), yang diakhiri dengan dukungan pada perangkat lunak lengkap yang dihasilkan (Pressman, 2012).

Tahapan tahapan dari metode waterfall adalah sebagai berikut:

a. Requirement Analisis

Tahap ini pengembang sistem diperlukan komunikasi yang bertujuan untuk memahami perangkat lunak yang diharapkan oleh pengguna dan batasan perangkat lunak tersebut. Informasi ini biasanya dapat diperoleh melalui wawancara, diskusi atau survei langsung. Informasi dianalisis untuk mendapatkan data yang dibutuhkan oleh pengguna.

b. System Design

Spesifikasi kebutuhan dari tahap sebelumnya akan dipelajari dalam fase ini dan desain sistem disiapkan. Desain Sistem membantu dalam menentukan perangkat keras(hardware) dan sistem persyaratan dan juga membantu dalam mendefinisikan arsitektur sistem secara keseluruhan. 
c. Implementation

Pada tahap ini, sistem pertama kali dikembangkan di program kecil yang disebut unit, yang terintegrasi dalam tahap selanjutnya. Setiap unit dikembangkan dan diuji untuk fungsionalitas yang disebut sebagai unit testing.

d. Integration \& Testing

Seluruh unit yang dikembangkan dalam tahap implementasi diintegrasikan ke dalam sistem setelah pengujian yang dilakukan masing-masing unit. Setelah integrasi seluruh sistem diuji untuk mengecek setiap kegagalan maupun kesalahan.

e. Operation \& Maintenance

Tahap akhir dalam model waterfall. Perangkat lunak yang sudah jadi, dijalankan serta dilakukan pemeliharaan. Pemeliharaan termasuk dalam memperbaiki kesalahan yang tidak ditemukan pada langkah sebelumnya. Perbaikan implementasi unit sistem dan peningkatan jasa sistem sebagai kebutuhan baru.

\subsection{Analisis Kebutuhan (Analysis Requirement)}

Dari hasil observasi dan wawancara di tempat Budidaya Jamur Rian, penulis menemukan permasalahan dan menganalisa bahwa sistem yang sedang berjalan selama ini masih kurang efektif, dikarenakan kurangnya promosi dan apabila konsumen ingin membeli atau memesan jamur, konsumen harus datang secara langsung untuk melakukan pembelian ataupun pemesanan. Bukan hanya itu pengolahan data hasil penjualan jamur masih dicatat secara manual. Dari kesulitan promosi, penjualan dan pengolahan data yang dialami oleh petani khususnya pada budidaya jamur rian, dengan memanfaatkan teknologi semua permasalahan yang terjadi dapat teratasi, maka penulis akan membangun E-Agriculture.

\subsection{Desain Sistem (Modeling)}

1) Perancangan Sistem

a) Use Case Diagram

Use Case Diagram merupakan pemodelan untuk kelakuan (behavior) sistem informasi yang akan dibuat (Hendini, 2016). Use case mendeskripsikan sebuah interaksi antara satu atau lebih aktor dengan sistem informasi yang akan dibuat dalam hal ini E-Agriculture Budidaya Jamur.

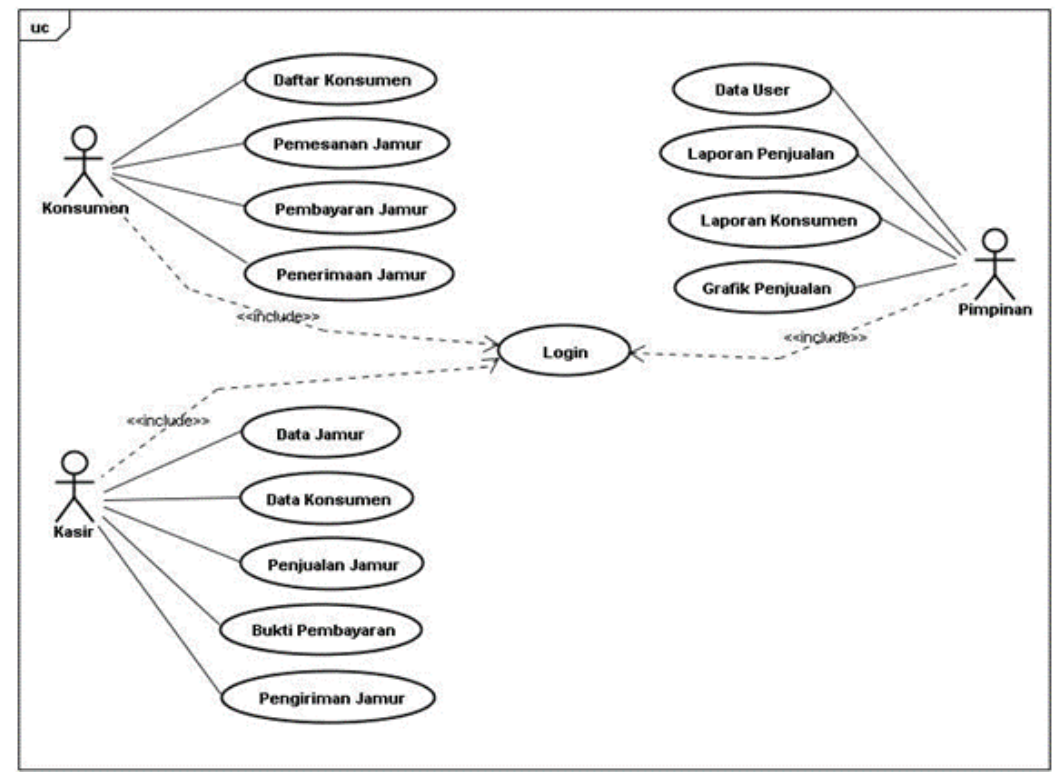

Gambar 1. Use Case Diagram E-Agriculture

b) Class Diagram

Perancangan class diagram menjelaskan bahwa semua class saling berelasi antar class satu dengan class lainnya. 


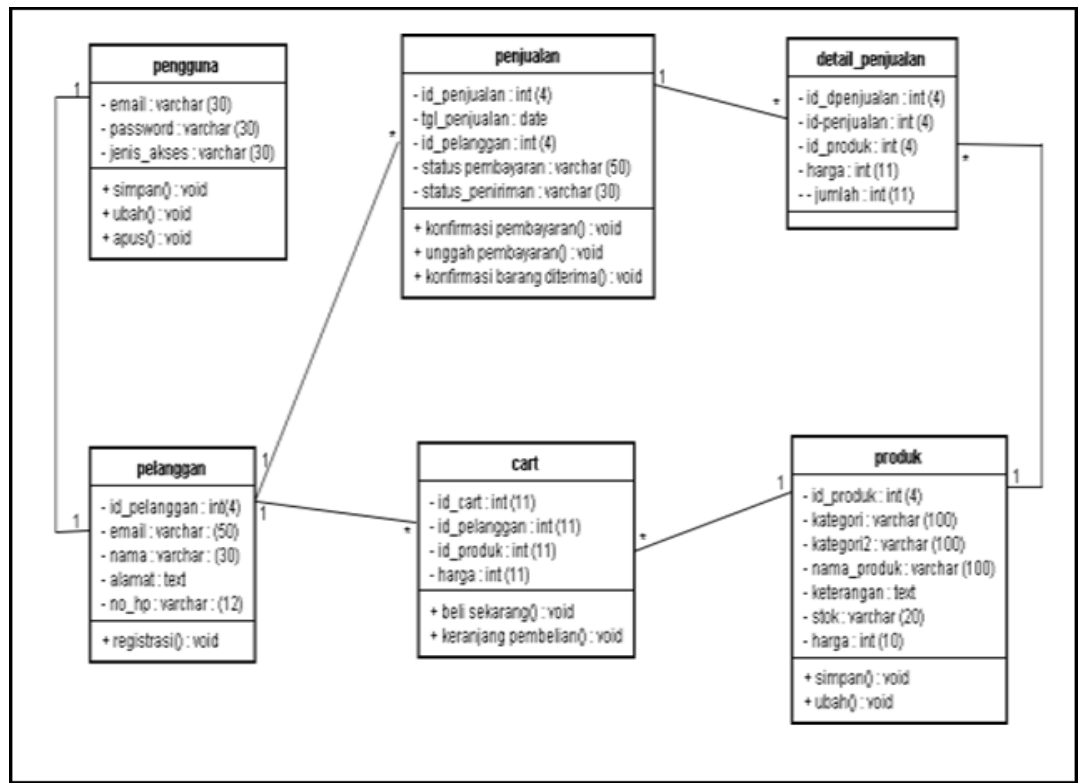

\section{Gambar 2. Class Diagram}

2) Perancangan Antarmuka

Perancangan antarmuka diperlukan dengan tujuan untuk mempermudah pengguna dalam menggunakan sistem informasi berbasis web (Gunawan, 2013).

a) Desain Halaman Registrasi

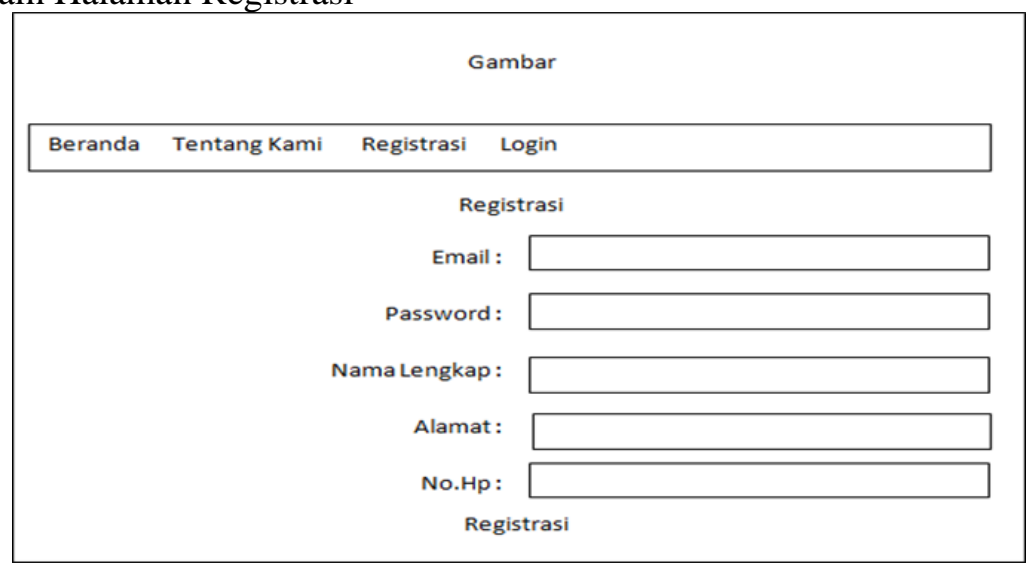

Gambar 3. Desain Halaman Registrasi

b) Desain Halaman Login

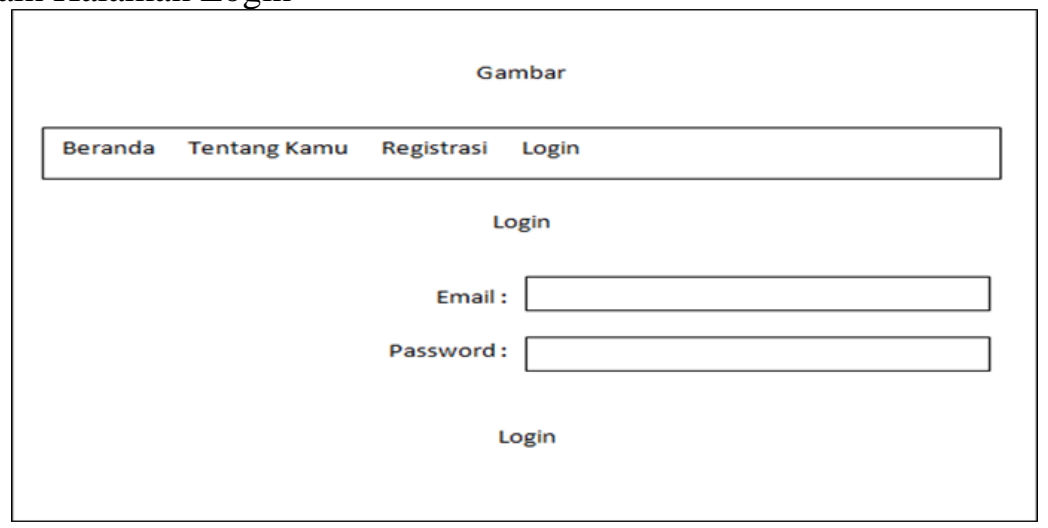

Gambar 4. Desain Halaman Login 
c) Desain Halaman Home

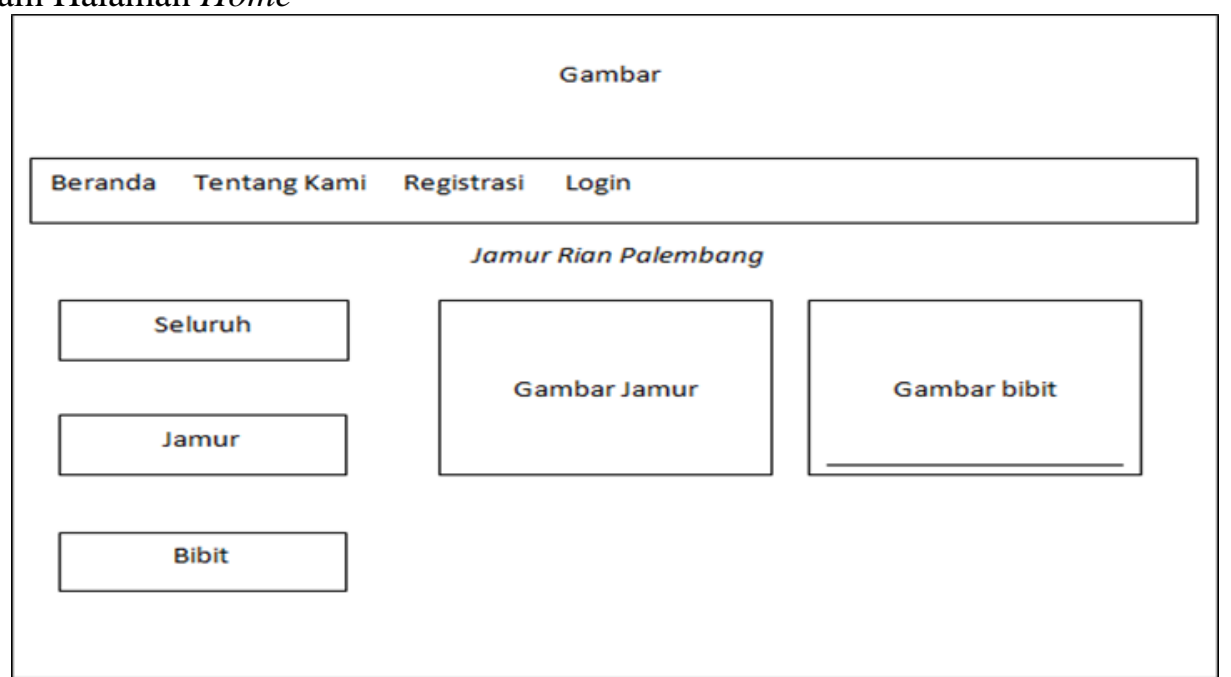

\section{Gambar 5. Desain Halaman Home}

d) Desain Halaman Produk Detail

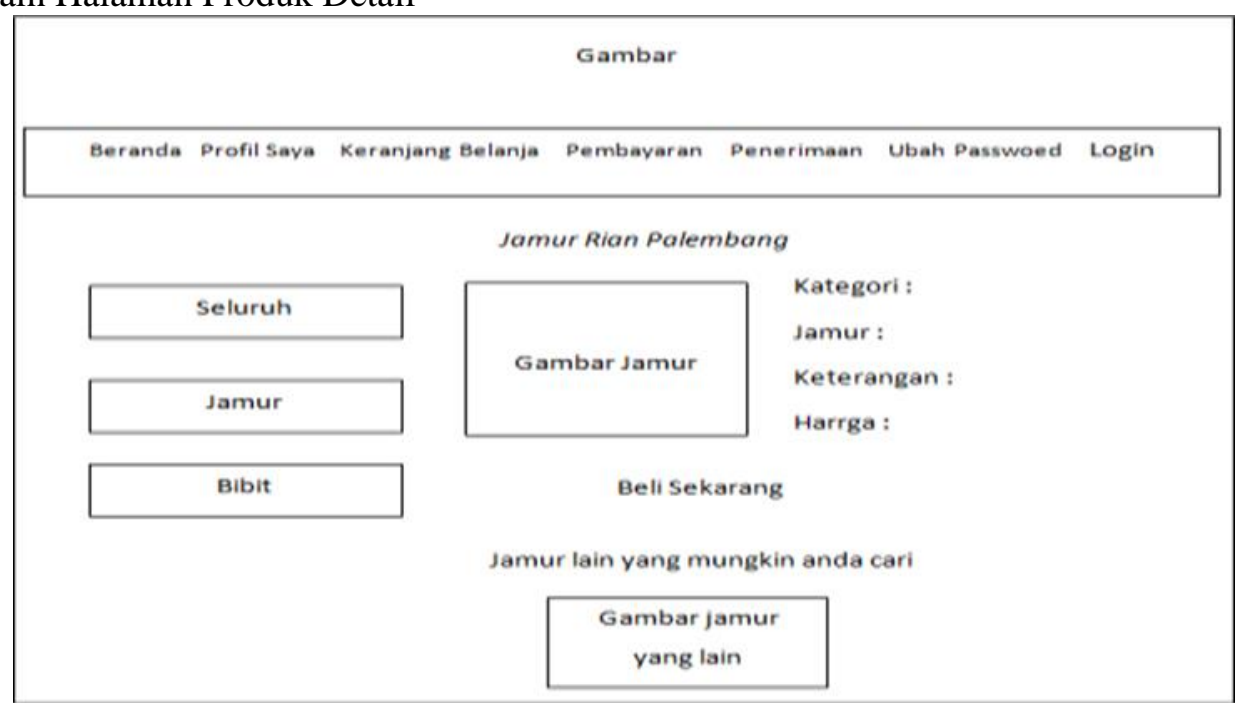

\section{Gambar 6. Desain Halaman Produk Detail}

\section{HASIL DAN PEMBAHASAN}

Setelah melakukan proses analisis kebutuhan dan pemodelan berupa sistem, struktur basis data dan antarmuka, selanjutnya dilakukan proses implementasi dan testing E-Agriculture Budidaya Jamur.

Pemanfaatan teknologi dalam bidang pertanian dapat mempermudah promosi dan penjualan hasil produk jamur. E-Agriculture dirancang dan dibangun agar pelanggan yang jauh dari tempat budidaya jamur dapat melihat dan memesan jamur tanpa harus datang ke lokasi budidaya jamur. 


\subsection{Implementasi}

1) Halaman Registrasi

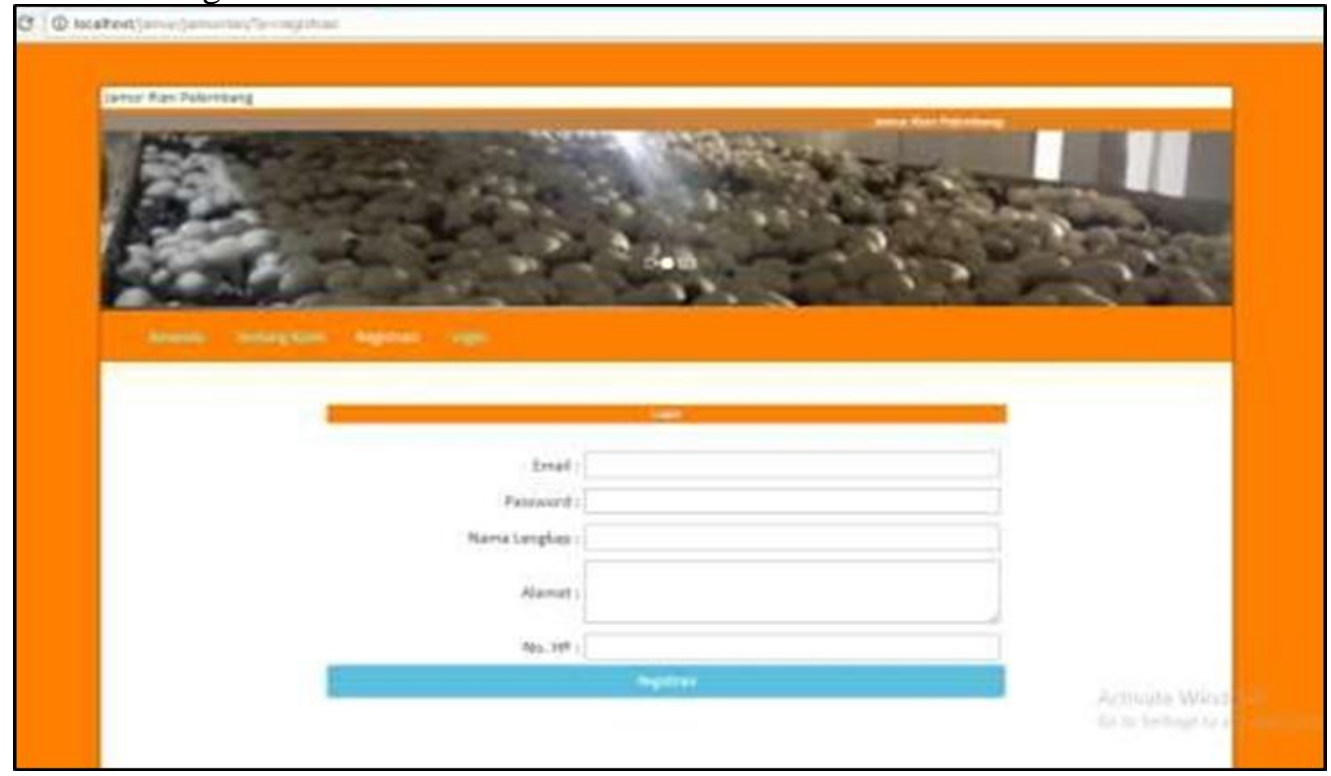

Gambar 7. Halaman Registrasi

2) Halaman Login

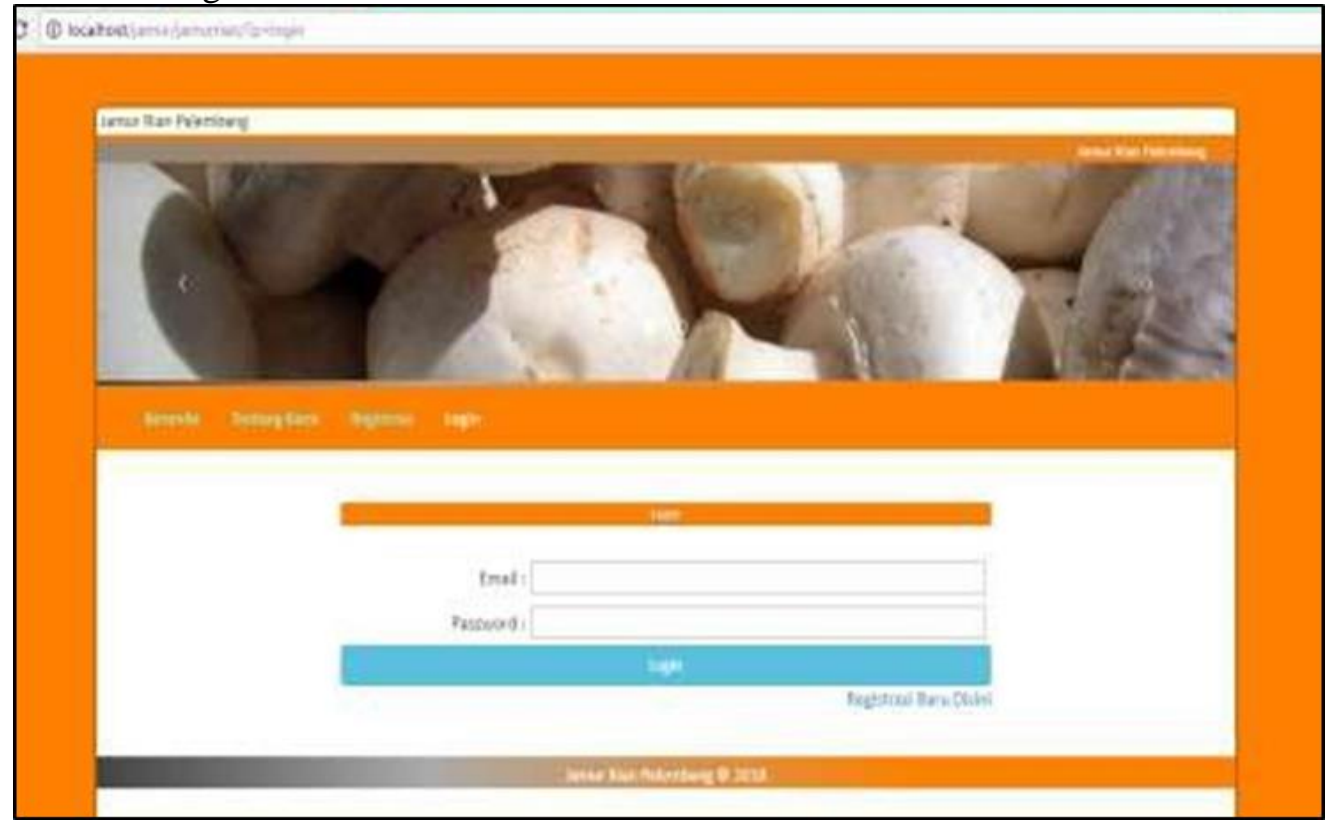

Gambar 8. Halaman Login 
3) Halaman Home E-Agriculture

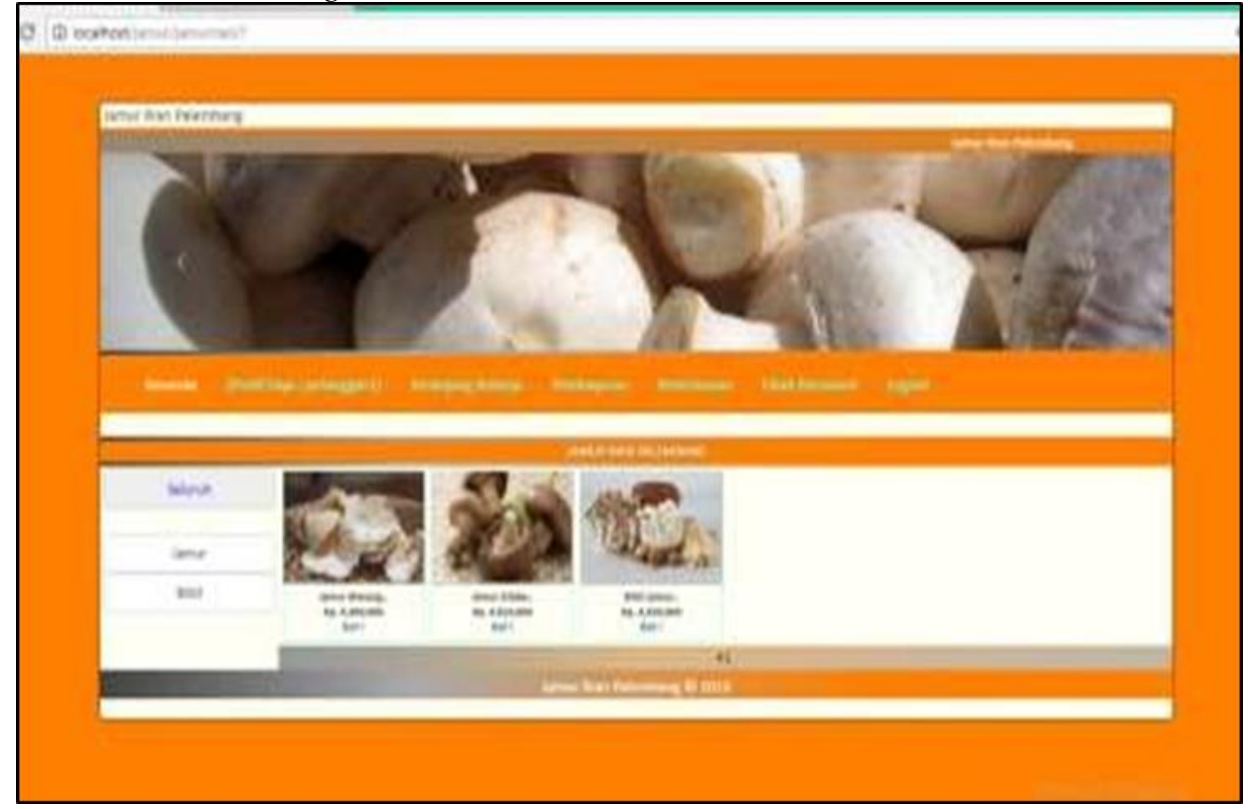

Gambar 8. Halaman Home E-Agriculture

4) Halaman Produk Detail

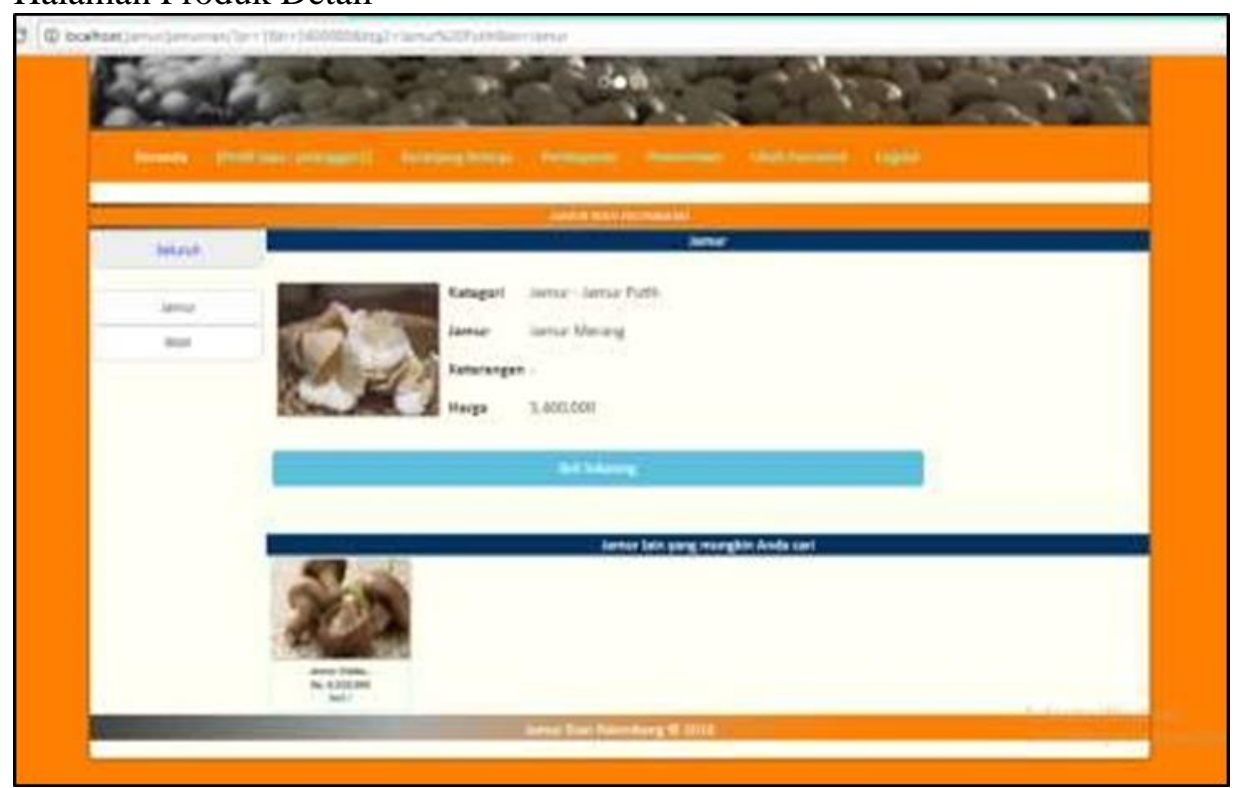

Gambar 9. Halaman Produk Detail 
5) Halaman Cart

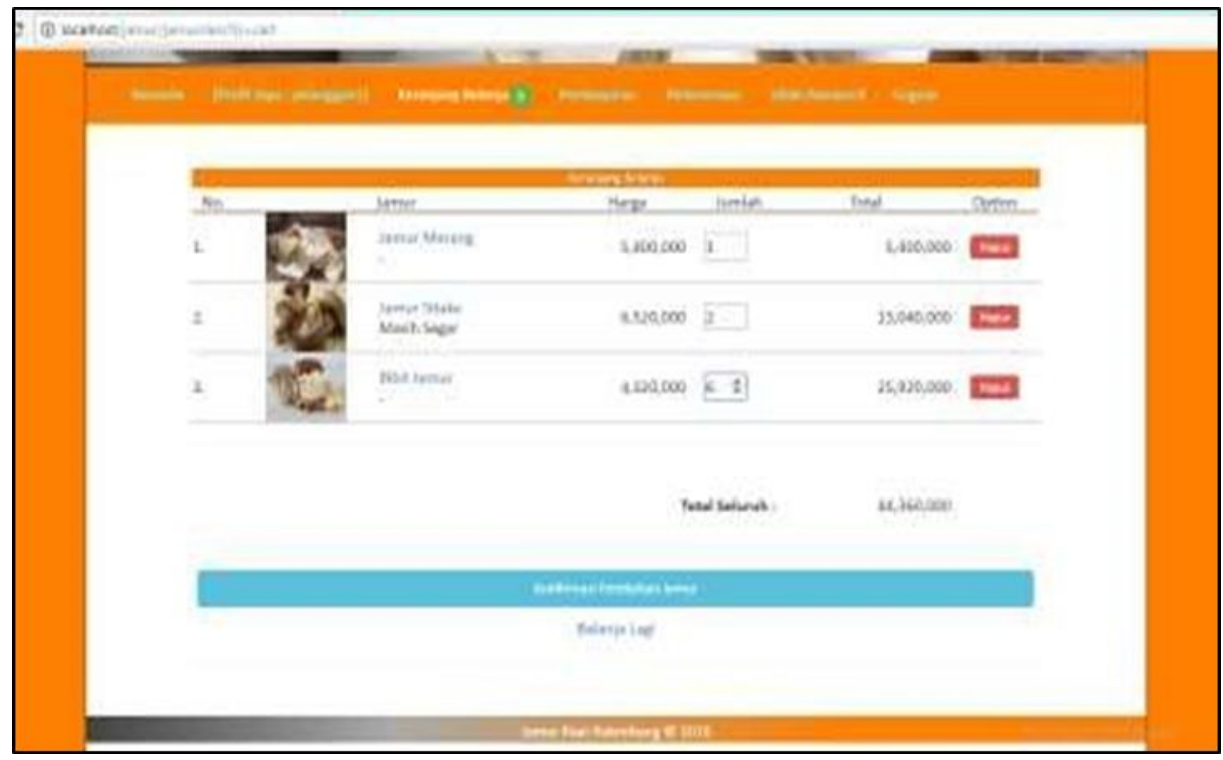

Gambar 10. Halaman Cart

6) Halaman Laporan Penjualan

\begin{tabular}{|c|c|c|c|c|c|}
\hline \multicolumn{6}{|c|}{ 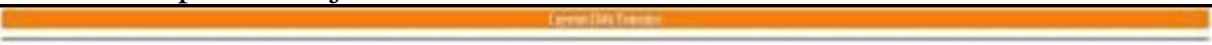 } \\
\hline $\mathbf{s}$ & Konewn & Tatar & Sun frolegr: & Sumpogenen: & Tow \\
\hline 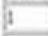 & 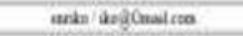 & 2114.4 & Rateyun liat & Burner That Dramia & 30000 \\
\hline 2 & 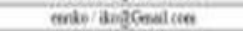 & Whens & Aoterue twat & Beres Thlat Derion & com \\
\hline 5 & 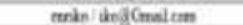 & (x)แ-3 & 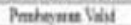 & 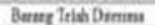 & 5000 \\
\hline 4 & mis acjonal cas & maths & Nembivan lwat & learar that Denias & timen \\
\hline 8 & 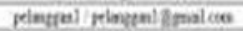 & Wustis & Podeywa wai & Bant Tdid Darm & wan \\
\hline 6 & meido dogignal ita & $2911-11-30$ & Pelogura livat & 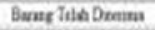 & $\$ 0000$ \\
\hline in & 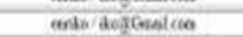 & (xis) & Federwe wat & Beser The Denias & 9000000 \\
\hline 1 & 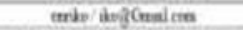 & 3016.120 & Mateun Wial & Bent Fild Demim & 20000000 \\
\hline i & 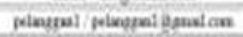 & (Dithet & Batsous iva & Samef ithe Dass & batow \\
\hline 10 & 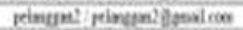 & Manisa & Penderven wal & Bami The Datrn & 3000 \\
\hline iI & mrio dog Conal en & $00: 1206$ & Dentoreul libet & Beare Tith Demina & 1000 \\
\hline 萿 & 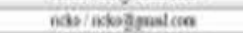 & (xat) & Nandeswe Wat & Dane the Dakn & 50000 \\
\hline $\mathrm{B}$ & nabs inej mal in & (50141201 & Renterves lad & Baras Relé Dùrm & 2000 \\
\hline 4 & mido disforaicese & DOLLDE & Datesua lad & Anes lita basen & $n 0000$ \\
\hline \multirow{3}{*}{ iI } & mis disfonalices & 9461212 & Pendense Whal & Bung Thad Darm & Noso \\
\hline & & & & Tenisant & 202150 \\
\hline & & & & & 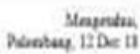 \\
\hline
\end{tabular}

\section{Gambar 11. Halaman Laporan Penjualan}

\subsection{Uji Coba}

Setelah dilakukan implementasi, dilakukan Uji coba terhadap E-Agriculture pada fungsi sistemnya menggunakan Blackbox Testing. Sebagai berikut:

\begin{tabular}{|c|l|l|l|r|}
\hline No & \multicolumn{1}{|c|}{$\begin{array}{c}\text { Fungsi } \\
\text { Yang Diuji }\end{array}$} & \multicolumn{1}{c|}{ Cara Pengujian } & \multicolumn{1}{|c|}{$\begin{array}{c}\text { Halaman Yang } \\
\text { Diharapkan }\end{array}$} & $\begin{array}{c}\text { Hasil } \\
\text { Pengujian }\end{array}$ \\
\hline 1 & Registrasi & $\begin{array}{l}\text { Konsumen melakukan } \\
\text { registrasi dengan } \\
\text { mengisi email, } \\
\text { password, nama } \\
\text { lengkap, alamat dan no } \\
\text { hp }\end{array}$ & $\begin{array}{l}\text { Setelah melakukan } \\
\text { registrasi konsumen } \\
\text { bisa melakukan login }\end{array}$ & Berhasil \\
& & & \\
\hline
\end{tabular}

Volume 5, Nomor 1, Juni 2019 


\begin{tabular}{|c|c|c|c|c|}
\hline No & $\begin{array}{c}\text { Fungsi } \\
\text { Yang Diuji }\end{array}$ & Cara Pengujian & $\begin{array}{l}\text { Halaman Yang } \\
\text { Diharapkan }\end{array}$ & $\begin{array}{c}\text { Hasil } \\
\text { Pengujian }\end{array}$ \\
\hline 2 & Login & $\begin{array}{l}\text { Konsumen } \\
\text { memasukkan email dan } \\
\text { password }\end{array}$ & $\begin{array}{l}\text { Konsumen masuk ke } \\
\text { halaman konsumen }\end{array}$ & Berhasil \\
\hline 3 & Beranda & Klik menu beranda & $\begin{array}{l}\text { Konsumen bisa } \\
\text { memilih jamur atau } \\
\text { bibit yang akan di } \\
\text { beli }\end{array}$ & Berhasil \\
\hline 4 & $\begin{array}{l}\text { Tampilan } \\
\text { Publik }\end{array}$ & Klik jamur atau bibit & $\begin{array}{l}\text { Apabila konsumen } \\
\text { memilih jamur } \\
\text { konsumen dapat } \\
\text { memilih jenis jamur } \\
\text { yang akan di beli }\end{array}$ & Berhasil \\
\hline 5 & $\begin{array}{l}\text { Halaman } \\
\text { untuk } \\
\text { melihat } \\
\text { jamur }\end{array}$ & Klik salah satu jamur & $\begin{array}{l}\text { Konsumen bisa } \\
\text { melihat kategori, } \\
\text { jamur, keterangan, } \\
\text { dan harga }\end{array}$ & Berhasil \\
\hline 6 & $\begin{array}{l}\text { Halaman } \\
\text { keranjang } \\
\text { barang }\end{array}$ & $\begin{array}{l}\text { Klik menu keranjang } \\
\text { barang }\end{array}$ & $\begin{array}{l}\text { Konsumen bisa } \\
\text { melihat jamur apa } \\
\text { saja yang telah di } \\
\text { beli }\end{array}$ & Berhasil \\
\hline 7 & $\begin{array}{l}\text { Tampilan } \\
\text { unggah } \\
\text { pembayaran }\end{array}$ & $\begin{array}{l}\text { Klik menu menu } \\
\text { pembayaran lalu pilih } \\
\text { choose file }\end{array}$ & $\begin{array}{l}\text { konsumen bisa } \\
\text { mengupload bukti } \\
\text { pembayaran }\end{array}$ & berhasil \\
\hline 8 & $\begin{array}{l}\text { Tampilan } \\
\text { penerimaan } \\
\text { barang }\end{array}$ & $\begin{array}{l}\text { Klik menu penerimaan } \\
\text { barang }\end{array}$ & $\begin{array}{l}\text { Konsumen bisa } \\
\text { Melihat dan } \\
\text { mengklik menu } \\
\text { konfirmasi barang } \\
\text { diterima bahwa } \\
\text { barang yang telah di } \\
\text { pesan telah } \\
\text { diterima }\end{array}$ & Berhasil \\
\hline
\end{tabular}

\section{KESIMPULAN}

Berdasarkan dari hasil penelitian yang dilakukan dalam pemanfaatan teknologi terhadap promosi dan penjualan hasil pertanian studi kasus membangun E-Agriculture budidaya jamur rian ini maka penulis dapat mengambil kesimpulan bahwa dapat mempermudah petani dalam memperluas promosi dan penjualan kepada pelanggan dengan cukup menggunakan sistem E-Agriculture untuk melakukan proses tersebut tanpa harus memasarkan hasil pertanian ke pelanggan yang jaraknya jauh dari pelanggan dan para pelanggan tidak harus ke tempat budidaya jamur secara langsung cukup dengan melihat dan memesan jamur melalui sistem E-Agriculture.

\section{DAFTAR RUJUKAN}

Gunawan, C. E. (2013). Sistem Informasi Seleksi Calon Mahasiswa Berbasis Web di Sekolah

Tinggi Teknik Musi Palembang. JUITA, 217-224. 
Hendini, A. (2016). Pemodelan UML Sistem Informasi Monitoring Penjualan dan Stok Barang (Studi Kasus: Distro Zhezha Pontianak). Jurnal Khatulistiwa Informatika, 107-116.

Jogiyanto. (2008). Metodologi Penelitian Sistem Informasi. Yogyakarta: Andi.

Pressman, R. (2012). Rekayasa Perangkat Lunak (Pendekatan Praktisi) Edisi 7. Yogyakarta: Andi.

Soekartawi, S. (2007). e-AGRIBISNIS: TEORI DAN APLIKASINYA. Seminar Nasional Aplikasi Teknologi Informasi 2007 (SNATI 2007), 19-25. 